\title{
Solid Waste Disposal Management Practices in Ghana, A Case Study of Subin Metropolis
}

\author{
Prince Owusu-Ansah (Corresponding author) \\ Department of Mechanical Engineering, Kumasi Technical University, Ghana \\ E-mail: prinosah1990@yahoo.co.uk
}

Saviour Kwame Woangbah

Department of Mechanical Engineering, Kumasi Technical University, Ghana

Benjamin Anim

Department of Mechanical Engineering, Kumasi Technical University, Ghana

Francis Azabu

Department of Mechanical Engineering, Kumasi Technical University, Ghana

Received: June 20, $2021 \quad$ Accepted: August 1, $2021 \quad$ Published: August 24, 2021

doi:10.5296/emsd.v10i4.18773 URL: https://doi.org/10.5296/emsd.v10i4.18773

\begin{abstract}
Solid waste management is a societal problem both in developed and developing countries and studies have shown that most developing nations are struggling to find a lasting solution to this bane. The study therefore, sought to assess the waste management practices in Ghana using Subin Metropolis as a case study and offer some solutions to the challenges faced by resident and city authorities in managing the problem. Subin Metropolis a suburb of Kumasi, is considered as one of the highly-dense suburbs in terms of its human population and social activities.

In this study, a set of structured questionnaires was administered to households selected randomly. The total number of households selected was based on statistics of the 2010 population census of one hundred and seventy-four thousand and four $(174,004)$ inhabitants. with an annual growth rate of $4.8 \%$, was used in projecting the number of inhabitants in the
\end{abstract}


suburb for 2020 being the year under consideration as 253192, was adopted using the Slovin's equation resulting in a sample size of four hundred (400). Data collected were analysed using SPSS and the results presented.

Findings of the research reveal that despite the provision of dustbin by Subin sub metro authority and waste management companies, $32.25 \%$ of the residents use inappropriate storage receptacles including plastic bags to store their refuse temporarily in the house.

$8.75 \%$ of residents dispose of their waste through waste companies using dump truck, $76 \%$ of the waste generated are evacuated through paid labourer for onward transportation to the few waste storage and collecting points within the metropolis. If the wastes at the storage point are not evacuated on time can lead to serious health implications.

Lack of access roads is a major hindrance to effective waste management in the community due to poor spatial planning. Inadequate information and education on waste management and alternative strategies on managing waste is also another limiting factor that contributed to the poor sanitary condition in the Metropolis.

This paper recommends using a multifaceted approach in solving the waste management menace through awareness creation, community engagement, information sharing as well as sustainable waste management systems such as waste reduction and recycling of waste. The paper also recommends that the city authority create more access roads in the community to improve upon waste services delivery.

Keywords: Dumpsite, Household, Solid waste management, Refuse, Storage, Receptacles

\section{Introduction}

\subsection{Waste Disposal Challenges}

Over the past decade, urbanisation in most cities in Ghana has brought about enormous pressure on infrastructure and services. This has resulted in a tremendous increase in unsanitary conditions within our environment and as such sanitation services on high demand. With the current trend in population growth concentrated in the cities, a significant portion of solid waste generated is expected to be generated in these urban cities and towns.

It is against this situation that city authorities in the country have not been able to keep pace with the associated growing waste disposal challenges. The nonexistence of adequate and suitable waste disposal services has given rise to waste build-up and a consequence unsanitary environment in several parts of the country. If the current mode of addressing the challenges of waste management systems is not changed, the enormous solid waste quantities which are expected to be generated in the coming years would pose greater health and environmental challenges in the hands of city authorities.

Owusu-Sekyere et al. (2013), revealed that solid waste generation in Greater Kumasi is expected to increase as a result of the high rate of urbanization in the metropolis and will continue to increase within the next couple of years. Hoornweg \& Bhada-Tata (2012) also anticipate a sharp upsurge in the volume of waste produced from urban residents. 


\section{Al Macrothink}

Environmental Management and Sustainable Development

ISSN 2164-7682

2021, Vol. 10, No. 4

In Ghana, waste management is managed by private waste management companies on behalf of local authorities such as Metropolitan, Municipal, and District Assemblies and it involves the collection and transportation of waste from the community to the dumping site. This practice is also done by most developing countries and in some instances' residents pay for the waste collected. (Okot-Okumu, 2012). Okot-Okum, also noted that good waste management services can use as a yardstick to measure the performance of local authorities in a city as for as sustainable municipal waste management reforms are a concern.

Ahmed \& Ali (2004) observed that developing nations are seriously grappling with waste management which has now become a social problem globally. According to World Health Organization (WHO) report, most governments of African countries identify solid waste as the second most important problem after the unavailability of the provision of quality water (Zerbock, 2003). It is for this reason, that Municipal Solid Waste Management (MSWM) is progressively gaining attention.

\subsection{Urbanisation and Waste generation in Kumasi Metropolis}

Kumasi Metropolitan Assembly (KMA), in recent times, has seen a considerable increase in its population growth due to migration mostly from the northern part of the country. In 2010, it was reported that an estimated number of over two million people live in the metropolitan area of Kumasi and has a growth rate of 5.4 percent (Nyanteng et al., 2013).

In the face of numerous economic benefits of urbanisation occurring, the metropolitan area has been deprived of functional infrastructure. This has manifested in the city's inability to manage the waste it generates due to inadequate infrastructure for collecting and disposal of waste in a sustainable manner within its land space.

A casual observation around the city shows that the KMA is burdened with a deteriorating waste management condition potentially leading to public health issues. Figure 1 shows, in the year 1995, it was estimated that the rate at which domestic waste was generated in Kumasi stood at six-hundred tons per day, by 2005, it has risen to one thousand tons per day; three years later, city authorities were collecting one thousand two hundred tons in a day and $2010 \mathrm{KMA}$ document showed one thousand five hundred metric tons of waste was being generated in a day.

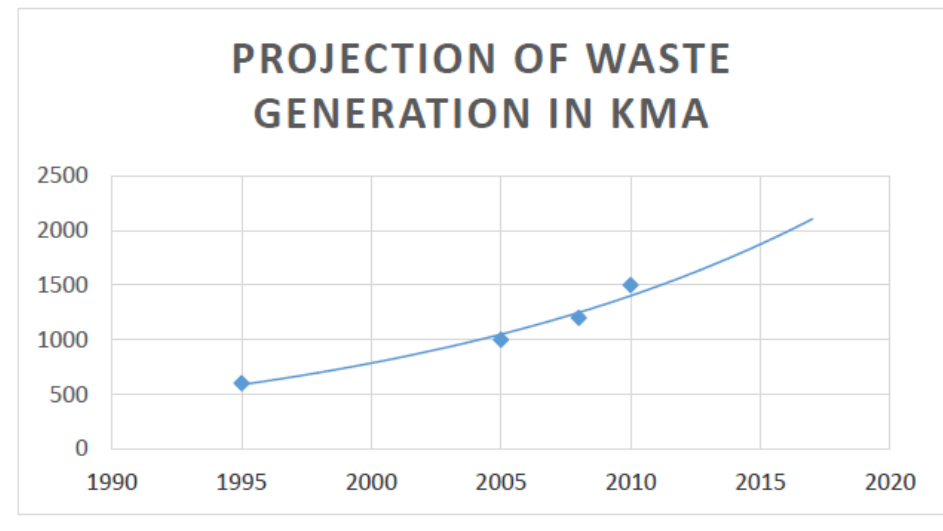

Figure 1. Projection of waste generation per day in KMA (Source data: WMD-KMA, 2012) 


\section{Macrothink}



Figure 2. Storage site at Asafo township

The waste generated has overwhelmed the city authorities and as such have not been able to manage the situation as expected. Figure 2 shows a temporal refuse storage site at a location within the city where the refuse has not been evacuated to the final dumpsite. The situation if not rectify can result in an outbreak of communicable diseases which could affect the life and health of the people tremendously within its vicinity.

This research paper seeks to establish the challenges in waste disposal practices in Subin sub-metropolitan areas and offer possible ways of managing them.

\subsection{Definition of Waste}

In an attempt to defined waste, Amasuomo \& Baird (2016), concluded that waste is to a large extent subjective in meaning as a material can only be considered as a waste when the owner labels it as such. This is particularly true because an item considered as waste can become a very valuable resource to another. Therefore, the definition of waste is very subjective. However, according to Gilpin (1996) waste can also be defined as unwanted materials arising entirely from human activities which are discarded into the environment.

Davies (2008), also defined waste as when an item is no more useful to its owner or fails to achieve its purpose.

Waste can therefore be defined as any undesirable and unusable by-products or residuals at any given place and time, and any other matter that may be rejected accidentally or otherwise into the environment. Unusable materials that originate from various sources such as households, businesses, agricultural as well as industrial enterprises and can be gaseous, liquid, or solid in nature, and toxic or non-toxic depending on where it is located its concentration.

Drawing from the several definitions of waste above, it is seen that waste is a relative term used to describe an item to be discarded. Waste can be seen as a resource being discarded. This view is asserted by Jessen (2002) that waste is essentially full of resources going in the wrong direction. 


\subsection{Waste Management Practices}

Management of solid waste viewed from a different perspective is the administration of activities that provide for the collection, source separation, storage, transportation, transfer, processing, treatment, and disposal of waste. Accordingly, if solid waste management is to be successful in an efficient and orderly manner, the vital aspects and relationships involved must be recognised and undoubtedly comprehended.

Basing on this argument, the integration of the following: source separation, storage, collection, transportation, and disposal of solid waste in an ecologically justifiable manner is very critical in solid waste management process should be well practiced.

According to Onibokun \& International Development Research Centre, IDRC (Canada) (1999) a number of cities in Africa in the 1980s established their municipal solid waste management strategies and programmes by governmental agencies with no considerable public involvement. As a result, Onibokun \& IDRC further noted that most of the cities were confronted with common challenges majority of which were managerial and organizational ineptitudes and this led to the non-existence distribution of responsibility for various activities of waste management.

Inappropriate disposal of waste in the environment has a destructive impact on the natural environment, health, and the overall quality of life of the people.

The challenges associated with landfills include odour, pests, ground and surface water contamination through leaching. With time, landfills reach their capacity, in the current pace of urbanisation findings, lands for the construction of new landfills have become a daunting task, costly and time-consuming.

Improper dumping of waste into the environment leads to the destruction of the ozone layer with numerous associated effects on the environment. When solid wastes are dumped in drainage channels and gutters, they block the flow of the sewerage. Blocking of the flow of sewerage has been attributed as the cause of flooding which destroys human lives and properties (Adu-Boahen et al., 2014).

Indiscriminate littering devalues the land around it and this has an undesirable impression in the area of tourism and businesses. When waste is not properly disposed of, it impedes the recovery of resources by way of recycling these wastes which usually consist of plastics, metals, and papers which are very dangerous to aquatic life (Miezah et al., 2015).

\subsection{Waste Composition}

Available data from KMA-WMD and Zoomlion Ghana Limited in a report show that the major component of refuse collected in the metropolis was organic materials.(Oriental Consultants Co. Ltd et al., 2013). This is shown in figure 3.

A considerable proportion of the wastes generated are plastics which could be attributed to the increasing use of plastic products due to its demand in usage, as in shopping places, in the services of food packaging, production of bottled and sachet water, and in manufacturing of household items such as plates and cups. 


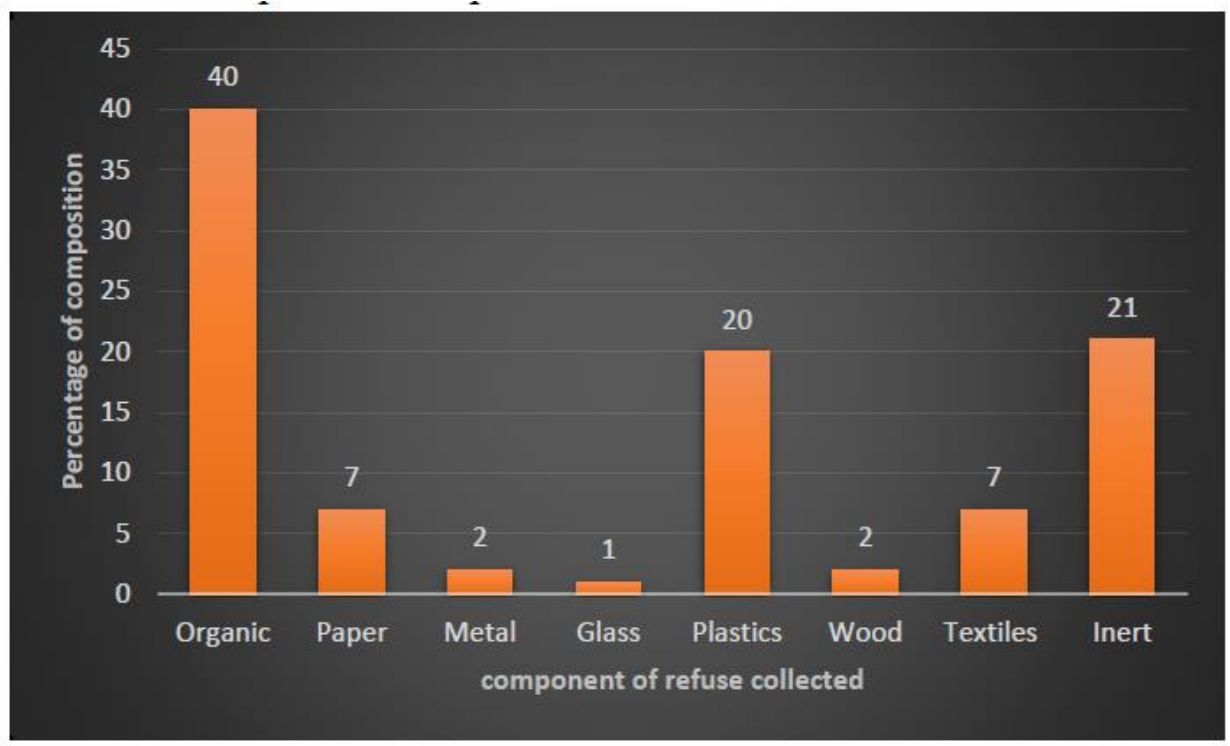

Figure 3. Component of Refuse Collected.

\section{Method}

\subsection{Geographical Area of Research Study}

Subin Sub-Metro is located in the heart of the Kumasi Metropolis and covers an area of one hundred and eighty square kilometres. It is found on latitude $6.35^{\circ}-6.40^{\circ}$ and longitude $1.30^{\circ}$ $-1.35^{\circ}$, at an elevation of 232 feet.

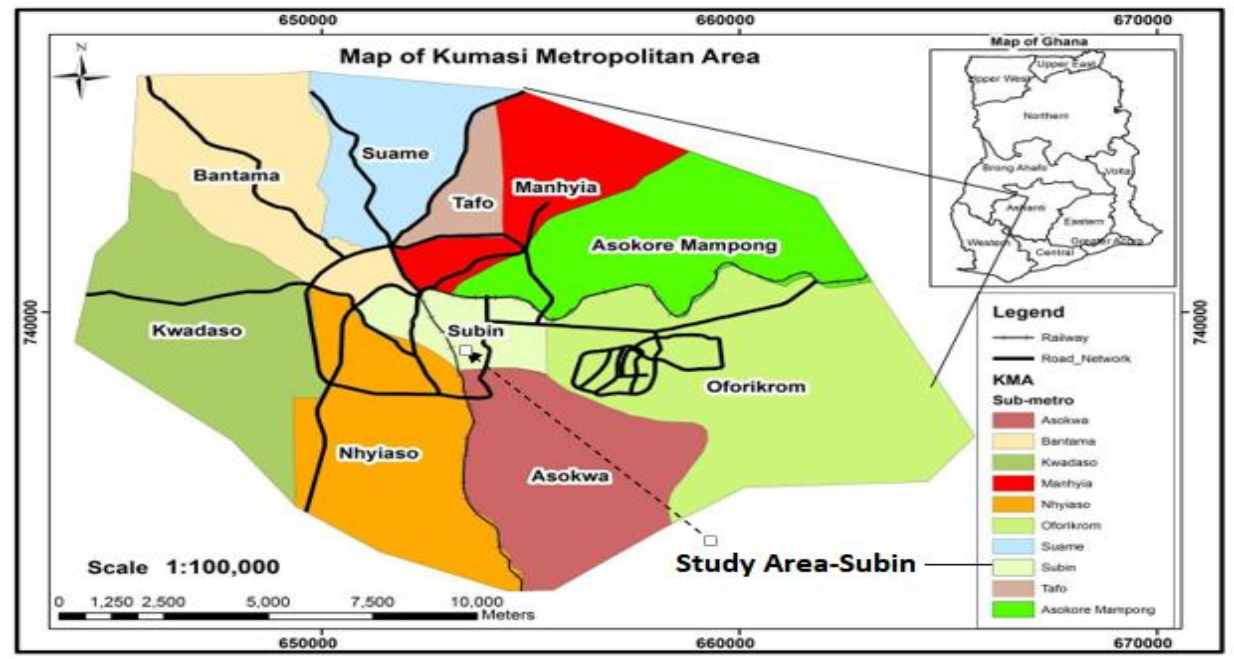

Figure 4. Map of Ghana showing KMA and the study area Subin

\subsection{Participant Characteristics}

Five suburbs were selected under the Subin Sub-Metro for the study. These included Asafo, 
Adum, Fante New Town, Anlo Fante Town, and Asem. n approximately equal number of residents who volunteered willingly were randomly selected in this research. Participants included were adult males and females who are considered a major stakeholder in household waste management.

\subsection{Sampling Procedures}

\subsubsection{Sample Size}

Based on the statistics of the 2010 population census of one hundred and seventy-four thousand and four $(174,004)$ with an annual growth rate of $4.8 \%$, which projected the number of inhabitants in 2020 as 253192, hence the sample size for research work was adopted using the Slovin's equation

$$
n=\frac{N}{1+N(e)^{2}}
$$

where $n=$ sample size,$N=$ Total population $e=$ error margin

with a confidence level of $95 \%$, the margin of error is 0.05

$$
n=\frac{253192}{1+253192(0.05)^{2}}=399.39
$$

hence a sample size of 400 was adopted for this research work.

\subsubsection{Research Design}

In this study, a set of primary data was generated through a survey. The data gathered was facilitated by a set of structured questionnaires. A mixed methods research strategy involving a research paradigm integrating both quantitative and qualitative research methods was used for the collection of data. The data gathered were analysed using Statistical Package for the Social Sciences (SPSS) software.

\subsubsection{Questionnaire}

A set of structured questionnaires touch on aspects of information such as; type of storage receptacles used by households for storing waste, means of disposal of solid wastes, how they frequently dispose of their waste, how far is the house from the temporal waste collection points, size of the refuse container at the collection point, general condition at collection point. The Additional data collected relates to respondents' access to information on solid waste management, knowledge level of waste management practices in their locality.

\subsubsection{Procedure}

The sample of households was selected randomly and questionnaires were administered to the head of household who willingly partake in the survey.

Pre-test questionnaires were administered to samples of households to ensure a clear understanding of the questions and instructions contained therein by the research team and respondents, minimising errors and nonresponse rate, and ensuring reliability and validity of 


\section{Macrothink}

Environmental Management and Sustainable Development

ISSN 2164-7682

2021, Vol. 10, No. 4

data collected. In order to ensure the confidentiality of the respondent, information such as name and residential address was not recorded.

\section{Results and Discussion}

Table 1 is the demographic characteristics of the respondents. In this table, more females willingly participated in the study than men. This result is collaborated by Asi et al. (2013) that women play a pivotal role in solid waste management issues and that waste management in households is basically women's job in developing countries. Asi et al. further reveal that full integration and awareness of women's responsibilities at all levels is vital for sustainable waste management.

Table 1. Respondents' Demographic Characteristics

\begin{tabular}{|l|l|l|}
\hline & Frequency & Percentage \\
\hline Sex & & \\
\hline Male & 145 & 36.25 \\
\hline Female & 255 & 63.75 \\
\hline Educational Level & & \\
\hline Non & 21 & 5.25 \\
\hline Primary & 38 & 9.50 \\
\hline JHS & 93 & 23.25 \\
\hline SHS/Technical/Vocational & 132 & 33.00 \\
\hline Tertiary & 116 & 29.00 \\
\hline Occupation & & \\
\hline Public/Civil Servant & 205 & 51.25 \\
\hline Private & 126 & 31.50 \\
\hline Unemployed & 69 & 17.25 \\
\hline Income level (Ghc) & & \\
\hline High(above 3000) & 89 & 22.25 \\
\hline Average(2000-3000) & 201 & 50.25 \\
\hline Low(below 2000) & 110 & 27.50 \\
\hline Number of occupants & & \\
\hline $1-3$ & 92 & 23 \\
\hline $4-6$ & 241 & 60.25 \\
\hline 7 and above & 67 & 16.75 \\
\hline
\end{tabular}

\subsection{Households Solid Waste Disposal Practices}

Although the majority of residents in Subin use refuse bins provided by a waste management ZoomLion Company Limited, a waste management company, they are only able to evacuate $8.75 \%$ of the waste generated in households as indicated in table 2 . This low figure is due to the lack of accessible roads and poor residential and spatial planning in the community which makes it difficult for waste management trucks to embark on a house-to-house collection of 


\section{Macrothink}

refuse. For these reasons, the majority of residents, $76 \%$ as shown in the table patronise the services of paid labourers for the evacuation of household waste on tricycles and wheelbarrows to the public dumpsite. Douti et al. (2017) found that the existence of a weak waste transportation system and low patronage of the house-to-house collection method are factors that adversely affect waste collection and evacuation systems.

Table 2 further indicates that for ease of transporting refuse to the public damp site, households resort to the use of other inappropriate storage receptacles such as plastic bags. The use of inappropriate refuse storage receptacles and the distance to the waste collection point encourages the indiscriminate dumping of refuse. Plastic bags account for $15.75 \%$ of the type of receptacles used for storing refuse in homes, the next highest after refuse bins which are $67.75 \%$. The rest constitutes $17 \%$. Douti et al also noted that the insufficient provision of waste collection bins contributed to poor waste management in urban areas.

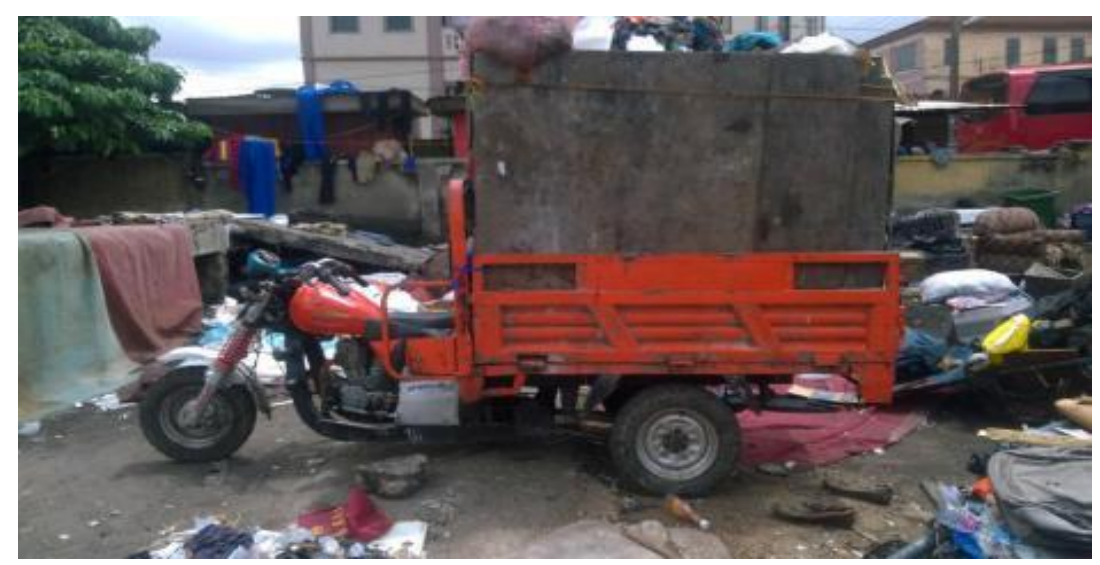

Figure 5. The use of tricycle for transporting waste to refuse collecting point

Table 2 indicates the modes adopted by households in the segregation of refuse 


\section{Mll Macrothink \\ Environmental Management and Sustainable Development \\ ISSN 2164-7682 2021, Vol. 10, No. 4}

Table 2. Households solid waste disposal practices

\begin{tabular}{|l|l|l|}
\hline \multicolumn{2}{|l|}{ Frequency } & Percentage \\
\hline \multicolumn{2}{|l|}{ Solid waste segregation at before disposal } \\
\hline Yes & 14 & 3.5 \\
\hline No & 386 & 96.5 \\
\hline Type of storage receptacles used by households for storing waste \\
\hline Refuse bin & 271 & 67.75 \\
\hline Plastic bags & 61 & 15.25 \\
\hline Drum & 8 & 2.00 \\
\hline Sacks & 24 & 6.00 \\
\hline Bucket & 23 & 5.75 \\
\hline Others & 13 & 3.25 \\
\hline Means of solid waste disposal of households \\
\hline Collected by ZoomLion & 35 & 8.75 \\
\hline Burned by household & 30 & 7.5 \\
\hline Public dump (Paid labourer) & 304 & 76.00 \\
\hline Public dump(self) & 15 & 3.75 \\
\hline Buried by household & 13 & 3.25 \\
\hline Others & 3 & 0.75 \\
\hline The frequency at which households dispose of waste \\
\hline Daily & 253 & 63.25 \\
\hline Weekly & 102 & 25.50 \\
\hline Occasionally & 45 & 11.25 \\
\hline Distance to collection points & 22 & 5.50 \\
\hline $50 m$ & 62 & 15.50 \\
\hline $100 \mathrm{~m}$ & 143 & 35.75 \\
\hline 150 & 173 & 43.25 \\
\hline More than 150 & \multicolumn{2}{|l|}{} \\
\hline
\end{tabular}

\subsection{Waste Management Practices}

Access to information and the involvement of all stakeholders in solid waste management is critical for the effective implementation of waste management policies. On the contrary, access to information is rather on the low side as $24.25 \%$ of respondents indicate they have access to information on solid waste. Lack of information sharing is a factor in the poor evacuation of refuse in their area as resident assumes that it is the full responsibility of authorities in seeing to the evacuation of refuse generated especially in public places and gathering.

Douti et al (2017) show that there is insufficient public awareness relating to waste management as well as lack of participatory approach by stakeholders in the waste management system. However, Sinthumule \& Mkumbuzi, (2019), found that the Community 
Bases Solid Waste Management (CBSWM) has not been successful in altering the waste disposal behaviour of inhabitants. Sinthumule \& Mkumbuzi, also noted that the community-based organisations (CBOs) have made no effort to implement alternative waste management practices of waste recycling and composting.

Jaouda Hamad et al., (2017) agree that the problem of awareness in solid waste management must be tackled immediately. Jaouda Hamad et al., further noted that local authorities in charge of the SWM seemed to lack experience as well as facilities required for proper solid waste management while residents also showed lack of awareness on recycling solid waste.

In furtherance, (Adu-Boahen et al., 2014) recommended education and awareness creation by environmental health officers and health professionals through the engagement of community leaders improve to improve sanitation, ensure a clean environment. In addition, Yukalang et al. (2018) opined that the many challenges of waste management require a deep understanding of the situation within the local context relating to specific issues and will require considerable community based consultation and engagement.

In tackling waste management problems, Liyanage et al. (2015) noted turning organic waste into compost and incinerating non-organic waste are important treatment methods for solid-waste management. Liyanage et al also found that reduction of solid waste is a critical process for sustainable management but people do not have much interest in waste recycling which has the potential to decrease the cost of solid-waste management. Gyimah et al.,(2021) found that most residents, irrespective of their income status hardly separate their solid waste. However, there are positive signs that residents are willing to separate waste at source, especially, when there is demand and market for the separated waste (Gyimah et al., 2021)

According to Sarbassov et al. (2019), some residents are already sorting household solid waste despite the absence of a separation system at the source. Sarbassov et al. further demonstrated that separation at source could be effective if local authorities introduce sound public awareness campaigns and install recycling bins in close proximity to residential buildings. 
Table 3. Respondents' Perceptions and Knowledge of Waste Management System

\begin{tabular}{|c|c|c|}
\hline & Frequency & Percentage \\
\hline \multicolumn{3}{|c|}{ Accessibility to information on solid waste management } \\
\hline Access to information & 97 & 24.25 \\
\hline No access to information & 303 & 75.75 \\
\hline \multicolumn{3}{|c|}{ Refuse evacuator in your area is done by } \\
\hline Zoom lion & 218 & 54.5 \\
\hline Sub-Metro & 82 & 20.5 \\
\hline Community & 33 & 8.25 \\
\hline Voluntary organisation & 67 & 16.25 \\
\hline \multicolumn{3}{|c|}{ Frequency of refuse evacuation from the collection points } \\
\hline When the container is full & 128 & 32 \\
\hline Weekly & 110 & 27.50 \\
\hline Monthly & 95 & 23.75 \\
\hline Once in a while & 67 & 16.75 \\
\hline \multicolumn{3}{|c|}{ Size of refuse container at collection point } \\
\hline Adequate & 84 & 21 \\
\hline Not adequate & 316 & 79 \\
\hline \multicolumn{3}{|c|}{ State of refuse container at collection point } \\
\hline In good condition & 136 & 34 \\
\hline Not in good condition & 264 & 66 \\
\hline \multicolumn{3}{|c|}{ General condition at collection point } \\
\hline Excellent & 12 & 3 \\
\hline Good & 84 & 21.00 \\
\hline Fair & 103 & 25.75 \\
\hline Poor & 201 & 50.25 \\
\hline \multicolumn{3}{|c|}{ Importance of work of the waste management personnel } \\
\hline Very Important & 102 & 25.5 \\
\hline Important & 133 & 33.25 \\
\hline Moderate important & 87 & 21.75 \\
\hline Little important & 51 & 12.75 \\
\hline Unimportant & 27 & 6.75 \\
\hline \multicolumn{3}{|c|}{ Waste management practices by authorities are effective in your area } \\
\hline Strongly agree & 21 & 5.25 \\
\hline Agree & 56 & 14.00 \\
\hline Undecided & 87 & 21.75 \\
\hline Disagree & 115 & 28.75 \\
\hline Strongly disagree & 121 & 30.25 \\
\hline
\end{tabular}

It is the view of this paper that alternative methods managing solid waste must be strongly looked at particularly recycling of solid waste. Solid waste can be effectively managed if it is 
separated at the point where it is generated such as homes, marketplaces, and factories. Whiles organic materials are bio-degradable, plastics are not as such these organic materials can be converted into organic fertilizer as well as for energy generation whiles plastics can be recycled. Combustible materials such as wood and textiles can be incinerated and those that cannot be subjected to any treatment be disposed of at the landfill, this will reduce the pressure on the landfill site.

\section{Conclusion}

The main components of solid waste generated in the Subin sub metropolis are organic waste and plastics. The study identified poor spatial planning as a major hindrance for effective waste management operations as a result, residence resort to the use of paid labourers to convey these solid wastes generated to a temporal dump site available to be evacuated by the city authorities. The most common means of transporting such refuse is by the used tricycle or motorised tricycle due to the inability of waste garbage trucks to access most residential areas to collect this refuse.

With proper spatial planning, garbage trucks will have embarked on a house-to-house collection of refuse and send them to the permanent dumping without having to send them to the temporal storage site in the community as in the case of the use of tricycles.

The study also identified lack of information and awareness on waste management by residents as another problem limiting effective waste management in the Subin Metropolis.

With adequate information and awareness on waste management residence will be abreast with alternative waste management strategies such as reduction of waste and recycling of waste. This will reduce the huge amount of waste at the temporal dumping site in the community. dumping site as well.

This paper concludes that the solution to the waste management problem in the Subin Metropolis can be best managed using a multifaceted approach. Awareness creation on alternative and more sustainable waste management system information shearing and engaging the people in the community particularly women in the waste management hierarchy.

The government and the city authorities are also encouraged to create more access roads in the community to improve upon the spatial planning to enhance the delivery of waste management services.

\section{References}

Adu-Boahen, K., Atampugre, G., Antwi, K. B., Osman, A., Osei, K. N., Mensah, E. A., \& Adu-Boahen, A. O. (2014). Waste management practices in Ghana: Challenges and prospect, Jukwa Central Region. International Journal of Development and Sustainability, 3(3), 530-546.

Ahmed, S. A., \& Ali, M. (2004). Partnerships for Solid Waste Management in Developing Countries: Linking Theories to Realities. Habitat International, 28, 467-469. 
https://doi.org/10.1016/S0197-3975(03)00044-4

Amasuomo, E., \& Baird, J. (2016). The Concept of Waste and Waste Management. Journal of Management and Sustainability, 6(4), 88. https://doi.org/10.5539/jms.v6n4p88

Asi, E., Busch, G., \& Nkengla, L. (2013). The Evolving Role of Women in Sustainable Waste Management in Developing Countries- A Proactive Perspective? South Africa, 3.

Davies, A. R. (2008). The Geographies of Garbage Governance: Interventions Interactions and Outcomes. Ashgate.

Douti, N. B., Abanyie, S. K., Ampofo, S., \& Nyarko, S. K. (2017). Solid Waste Management Challenges in Urban Areas of Ghana: A Case Study of Bawku Municipality. International Journal of Geosciences, 08(04), 494-513. https://doi.org/10.4236/ijg.2017.84026

Gilpin. (1996). Dictionary of Environment and Development. John Wiley and Sons.

Gyimah, P., Mariwah, S., Antwi, K. B., \& Ansah-Mensah, K. (2021). Households' solid waste separation practices in the Cape Coast Metropolitan area, Ghana. GeoJournal, 86(2), 567-583. https://doi.org/10.1007/s10708-019-10084-4

Hoornweg, D., \& Bhada-Tata, P. (2012). What a Waste: A Global Review of Solid Waste Management. World Bank, knowledge papers no. 15. [Online] Available:

https://openknowledge.worldbank.org/handle/10986/17388

Jaouda Hamad, J. R., Hanafiah, M. M., John, A. B., \& Sheikh, H. I. (2017). The Practice, Challenges and Awareness of Residential Solid Waste Management in the City of Al -Marj, Libya. Environment \& Ecosystem Science, 1(1), 23-27.

https://doi.org/10.26480/ees.01.2017.23.27

Jessen, M. (2002). The Ripple Effect of Zero Waste. Recycling Council of British Columbia (RCBC).

Liyanage, B. C., Gurusinghe, R., Herat, S., \& Tateda, M. (2015). Case Study: Finding Better Solutions for Municipal Solid Waste Management in a Semi Local Authority in Sri Lanka. Open Journal of Civil Engineering, 05(01), 63-73. https://doi.org/10.4236/ojce.2015.51007

Miezah, K., Obiri-Danso, K., Kádár, Z., Fei-Baffoe, B., \& Mensah, M. Y. (2015). Municipal solid waste characterization and quantification as a measure towards effective waste management in Ghana. Waste Management, 46, 15-27.

https://doi.org/10.1016/j.wasman.2015.09.009

Nyanteng, V. K., Peprah, P. T., Acheamfuor, L. B., Tawiah, E. N. O., \& Gaisie, S. K. (2013). Copyright @ 2013 Ghana Statistical Service. pp. 230.

Okot-Okumu, J. (2012). Solid Waste Management in African Cities - East Africa. pp. 3-20. https://doi.org/10.5772/50241

Oriental Consultants Co. Ltd, CTI Engineering International Co. Ltd, \& ALMEC Corporation. (2013). The Study on the Comprehensive Urban Development Plan for Greater Kumasi in the 
Republic of Ghana. The Study on the Comprehensive Urban Development Plan for Greater Kumasi in the Republic of Ghana.

Owusu-Sekyere, E., Harris, E., \& Bonyah, E. (2013). Forecasting and Planning for Solid Waste Generation in the Kumasi Metropolitan Area of Ghana: An ARIMA Time Series Approach. International Journal of Sciences, 2(04), 69-83.

Sarbassov, Sagalova, Tursunov, Venetis, Xenarios, \& Inglezakis. (2019). Survey on Household Solid Waste Sorting at Source in Developing Economies: A Case Study of Nur-Sultan City in Kazakhstan. Sustainability, 11(22), 6496.

https://doi.org/10.3390/su11226496

Sinthumule, N., \& Mkumbuzi, S. (2019). Participation in Community-Based Solid Waste Management in Nkulumane Suburb, Bulawayo, Zimbabwe. Resources, 8(1), 30. https://doi.org/10.3390/resources8010030

Yukalang, N., Clarke, B., \& Ross, K. (2018). Solid Waste Management Solutions for a Rapidly Urbanizing Area in Thailand: Recommendations Based on Stakeholder Input. International Journal of Environmental Research and Public Health, 15(7), 1302.

https://doi.org/10.3390/ijerph15071302

Zerbock, O. (2003). Urban Solid Waste Management. Michigan Technological University.

\section{Copyright Disclaimer}

Copyright for this article is retained by the author(s), with first publication rights granted to the journal.

This is an open-access article distributed under the terms and conditions of the Creative Commons Attribution license (http://creativecommons.org/licenses/by/4.0/). 